Article

\title{
Sugary Kefir: Microbial Identification and Biotechnological Properties
}

\author{
Maria K. Syrokou ${ }^{1}$, Marina Papadelli ${ }^{2, *}$, Ioanna Ntaikou ${ }^{2,3}$ (), Spiros Paramithiotis ${ }^{1}$ and \\ Eleftherios H. Drosinos ${ }^{1}$ \\ 1 Laboratory of Food Quality Control and Hygiene, Department of Food Science and Human Nutrition, \\ Agricultural University of Athens, Iera Odos 75, 11855 Athens, Greece; syrokoumargia@gmail.com (M.K.S.); \\ sdp@aua.gr (S.P.); ehd@aua.gr (E.H.D.) \\ 2 Department of Food Science and Technology, University of Peloponnese, 24100 Kalamata, Greece; \\ iwntaikou@chemeng.upatras.gr \\ 3 Institute of Chemical Engineering Sciences, Foundation for Research and Technology, 26504 Patra, Greece \\ * Correspondence: m.papad@teikal.gr; Tel.: +30-27-21045164
}

Received: 31 July 2019; Accepted: 8 October 2019; Published: 15 October 2019

check for updates

\begin{abstract}
Background: The aim of the present study was to assess the microecosystem composition of three different fruit kefir grains used for the fermentation of apple juice (NAJ), cherry juice (SCN), and a solution of sugary water, enriched with plums (BSS). Methods: Yeast and bacterial populations were enumerated using classical microbiological techniques, clustered by RAPD-PCR genotyping, and identified by sequencing of the D1/D2 region of 26S-rRNA gene and the V1-V3 region of 16S-rRNA gene, respectively. The caseinolytic/lipolytic activities and the production of antimicrobial compounds were assessed by well diffusion assays. The proteolytic and lipolytic capacity were further assessed by SDS-PAGE and titrimetric assay, respectively. Results: Yeast and bacterial populations were enumerated at 6.28, 6.58, and $6.41 \log \mathrm{CFU} / \mathrm{g}$ and at 4.32, 4.85, and $4.34 \log$ $\mathrm{CFU} / \mathrm{g}$, regarding BSS, NAJ, and SCN, respectively. Saccharomyces cerevisiae dominated all three sugary kefir grains; Kluyveromyces marxianus formed a secondary microbiota in BSS and NAJ. Bacillus amyloliquefaciens dominated NAJ and SCN; Lactobacillus rhamnosus dominated BSS. Four bacteria and nine yeast isolates exhibited proteolytic activity. Forty bacteria and 45 yeast isolates possessed lipolytic activity. No antibacterial activity was detected. Conclusions: Prevalence of yeast over bacterial populations was evident in all samples assessed. Several bacterial and yeast strains exhibited proteolytic and lipolytic activities, making them suitable candidates for inclusion in starter cultures for milk and sugary kefir fermentation.
\end{abstract}

Keywords: sugary kefir; apple; cherry; brown sugar; Lactobacillus rhamnosus; Bacillus amyloliquefaciens; Saccharomyces cerevisiae; Kluyveromyces marxianus

\section{Introduction}

Kefir is a self-carbonated, slightly acidic and alcoholic fermented beverage, with yeasty flavor, originating from Caucasian and para-Caucasian regions. It is typically manufactured by transferring kefir grains into a milk-based substrate. Kefir grains are yellowish-white, gelatinous, irregularly formed, variable in size and morphologically resembling small cauliflowers. These grains include a consortium of lactic acid bacteria (LAB) $\left(10^{8} \mathrm{CFU} / \mathrm{g}\right)$, yeasts $\left(10^{6}-10^{7} \mathrm{CFU} / \mathrm{g}\right)$, and occasionally acetic acid bacteria $\left(10^{5} \mathrm{CFU} / \mathrm{g}\right)$, attached to a polysaccharide matrix, known as kefiran [1].

In addition to using milk, an alternative substrate for kefir production has been the brown sugar solution. Sugary kefir beverage is based on sucrose solution with the addition of kefir grains, dried fruit and optionally some slices of lemon [2]. Although an association of sugary kefir grains with the 
ginger beer plants that were transferred from the Crimean War in 1855 has been documented, the roots of sugary kefir remain reasonably unclear [3]. Pidoux [4] used the term "sugary kefir grains" to distinguish them from the typical kefir grains.

Sugary kefir grains share plenty similarities with milk kefir grains in relation to their morphological characteristics and microcommunity composition. Many scientific reports have documented the presence of Lactobacillus casei, Lb. hordei, Lb. kefir, Lb. nagelii, Lb. parabuchneri, Lb. paracasei, Lb. rhamnosus, Leuconostoc citreum, and Ln. mesenteroides in sugary kefir grains [2,5,6]. As far as yeasts were concerned, the microcommunity includes Zygotorulaspora florentina, Kluyveromyces lactis, and Saccharomyces cerevisiae as the most prevalent species, being accompanied by Hanseniaspora valbyensis, Kazachstania aerobia, Lachancea fermentati, and L. meyersii [2,5].

The aim of this study was to identify the microorganisms present in three different samples of sugary kefir grains, produced by water enriched with sugar and plums, apple juice, and cherry juice. Furthermore, the technological properties associated with its production were studied, such as proteolytic and lipolytic capability, acidification potential, and antimicrobial activity against foodborne pathogens.

\section{Materials and Methods}

\subsection{Origin and Types of Sugar Kefir Grains}

The sugary kefir grains that were used in the present study were obtained via the conversion of classical milk kefir grains following gradual acclimatization to different substrates. The initial acclimation process from milk to sucrose fermentation lasted 5 days, during which lactose (whole fat milk) was progressively replaced by sucrose (brown sugar solution, BSS). For the preparation of the BSS, $46.5 \mathrm{~g}$ of commercial brown sugar ( $97 \%$ purity) was dissolved in $1 \mathrm{~L}$ of tap water and was supplemented with $10 \mathrm{~g}$ of dry prunes, with net sugar content $38 \%$, resulting thus to a solution of $50.3 \pm 0.2 \mathrm{~g} / \mathrm{L}$ total soluble sugars. The final fermentation test that was used for the isolation of microorganisms (sucrose derived) was conducted with $100 \%$ BSS as fermentation media. Subsequently, the sugar kefir grains were used for the fermentation of two different types of commercial juices i.e., sour cherry nectar (SCN) and natural apple juice (NAJ), after gradual acclimation to each new substrate according to the protocol described above.

\subsection{Fermentation Tests}

All fermentation tests were conducted at static batch conditions, at $25.0 \pm 0.2^{\circ} \mathrm{C}$, without initial $\mathrm{pH}$ adjustment. Kefir grains, priory acclimated to each substrate for 5 days, were introduced to fresh medium at a ratio of $5 \%,(\mathrm{w} / \mathrm{v}$, wet basis). After $24 \mathrm{~h}$ of fermentation, kefir grains were drained and their weight increase was estimated. The fermentation broth was analyzed in terms of final $\mathrm{pH}$ and concentration of fermentation products.

\subsection{Yeasts and Lactic Acid Bacteria Enumeration and Isolation}

Kefir grains (10 g) were homogenized with $90 \mathrm{~mL}$ sterile Ringer solution; serial decimal dilutions were prepared in the same diluent. Enumeration of lactic acid bacteria (LAB) and yeasts was carried out in De Mann, Rogosa, Sharpe agar (MRS) (LABM, Lancashire, UK) and in Rose-Bengal Chloramphenicol agar (RBC) (LABM) after pouring and spreading of serial dilutions and anaerobic (GasPak, BBL, Cockeysville, MD, USA) incubation at $30^{\circ} \mathrm{C}$ for $48 \mathrm{~h}$ and aerobic incubation at $25^{\circ} \mathrm{C}$ for $5 \mathrm{~d}$, respectively. From each sample, all colonies present in the final dilution were selected and purified by successive subculturing. $\mathrm{LAB}$ and yeast isolates were stored at $-20^{\circ} \mathrm{C}$ in Nutrient broth (LABM), supplemented with $50 \%$ glycerol. 


\subsection{Clustering and Identification of the Isolates}

Clustering of both yeast and LAB isolates was performed by PCR-RAPD using UBC155 as primer. More accurately, DNA was extracted according to Doulgeraki et al. [7]; each PCR mix consisted of $0.2 \mathrm{mM}$ dNTPs (Peqlab, Erlangen, Germany), $2.5 \mathrm{mM} \mathrm{MgCl} 2,1.5 \mu \mathrm{M}$ primer UBC155 (5'-CTG GCG GCT G-3') and 2 U Taq polymerase (Kapa Biosystems, MA, USA). Thermocycling conditions included initial denaturation step at $95^{\circ} \mathrm{C}$ for $2 \mathrm{~min}, 10$ cycles of $\left(95^{\circ} \mathrm{C}\right.$ for $1 \mathrm{~min}, 45^{\circ} \mathrm{C}$ for $1 \mathrm{~min}$ decreasing by $1{ }^{\circ} \mathrm{C}$ at each cycle to $36^{\circ} \mathrm{C}, 7{ }^{\circ} \mathrm{C}$ for $\left.2 \mathrm{~min}\right)$, then 30 cycles of $\left(95^{\circ} \mathrm{C}\right.$ for $1 \mathrm{~min}, 35^{\circ} \mathrm{C}$ for $1 \mathrm{~min}$, $72{ }^{\circ} \mathrm{C}$ for $2 \mathrm{~min}$ ), and a final extension step at $72{ }^{\circ} \mathrm{C}$ for $10 \mathrm{~min}$ [8]. PCR products were separated by electrophoresis in $1.5 \%$ agarose gel in $1.0 \times \mathrm{TAE}$ at $100 \mathrm{~V}$ for $1.5 \mathrm{~h}$, visualized by ethidium bromide staining and pictured using a GelDoc system (BioRad, Hercules, CA, USA). Bionumerics software (Applied Maths NV, Sint-Martens-Latem, Belgium) was used for conversion, normalization, and further analysis of the genotypic profiles obtained; clustering was obtained using the Dice coefficient and UPGMA analysis. In agreement with Doulgeraki et al. [7], one to three representative bacteria strains from each cluster were subjected to sequencing of the V1-V3 region of 16S-rRNA gene and the D1/D2 region of 26S-rRNA gene, for LAB and yeast isolates, respectively, for species identification.

\subsection{Assessment of Technological Properties}

\subsubsection{Proteolytic Activity}

Proteolytic activity of LAB and yeasts isolates was initially screened by an agar well diffusion assay and, in the case of positive result, further analyzed by sodium dodecyl sulfate-polyacrylamide gel electrophoresis (SDS-PAGE).

In the first case, $\mathrm{LAB}$ and yeast isolates were grown in MRS broth and BHI broth (LAB M) at 30 and $25^{\circ} \mathrm{C}$, respectively, for $24 \mathrm{~h}$. An amount $(50 \mu \mathrm{L})$ of the cell-free supernatant obtained by centrifugation $\left(12,500 \mathrm{rpm} ; 15 \mathrm{~min} ; 4^{\circ} \mathrm{C}\right)$ was placed into the wells that were punched into a solidified medium consisting of casein $1.0 \%$, tryptone $0.5 \%$, yeast extract $0.25 \%$, glucose $0.1 \%$, and agar $1.5 \%$ (pH 6.9 ). Incubation took place at 25 and $30{ }^{\circ} \mathrm{C}$ for $48 \mathrm{~h}$, for yeasts and $\mathrm{LAB}$, respectively. After incubation, plates were stained with Coomassie Brilliant Blue R (Sigma, Chemical Co., St. Louis, MO, USA); proteolytic activity was indicated by the presence of a clear zone surrounding the inoculated wells. Test was performed in triplicate.

The strains that exhibited proteolytic activity were further tested by SDS-PAGE. Actively growing $\mathrm{LAB}$ and yeast cells were inoculated into a broth medium consisted of tryptone $0.5 \%$, yeast extract $0.25 \%$, glucose $0.1 \%$, casein $1 \%(\mathrm{pH} 6.9)$, and incubated at 30 and $25{ }^{\circ} \mathrm{C}$, respectively, for $48 \mathrm{~h}$. Uninoculated broth served as a blank. Then, the cell-free supernatants were analyzed by SDS-PAGE according to Drosinos et al. [9]. Tests were performed in triplicate.

\subsubsection{Lipolytic Activity}

Lipolytic activity of LAB and yeasts isolates was initially screened by an agar well diffusion assay and, in the case of positive result, further analyzed by a titrimetric assay. In the first case, LAB and yeast isolates were grown in MRS broth and BHI broth (LAB M) at 30 and $25^{\circ} \mathrm{C}$, respectively, for $24 \mathrm{~h}$. An amount $(50 \mu \mathrm{L})$ of the cell-free supernatant obtained by centrifugation $\left(12,500 \mathrm{rpm} ; 15 \mathrm{~min} ; 4^{\circ} \mathrm{C}\right)$ was placed into the wells that were punched into a solidified medium consisting of nutrient agar, tributyrine $(1 \%)$ and DMSO $(0.25 \%)$. Incubation took place at 30 and $25{ }^{\circ} \mathrm{C}$ for bacterial and yeast strains, respectively, for 10 days. Presence of a transparent zone around the wells was an indicator of lipolysis. Test was performed in triplicate.

The strains that exhibited lipolytic activity were further analyzed by the titrimetric method proposed by Kamzolova et al. [10] with slight modifications. More accurately, actively growing cells of $\mathrm{LAB}$ and yeast strains were inoculated into a broth medium consisted of lecithin $0.5 \%$, tributyrine $1 \%$, meat extract $3 \mathrm{~g} / \mathrm{L}$ and peptone $5 \mathrm{~g} / \mathrm{L}$. Incubation took place at 30 and $25^{\circ} \mathrm{C}$ for bacterial and yeast strains, respectively, for 7 days. Uninoculated broth served at blank. After incubation, $10 \mathrm{~mL}$ of the 
cell-free supernatant obtained by centrifugation $\left(12,500 \mathrm{rpm} ; 15 \mathrm{~min} ; 4^{\circ} \mathrm{C}\right)$ was titrated with $50 \mathrm{mM}$ $\mathrm{NaOH}$ (to final $\mathrm{pH}$ value of 9.0). One unit (U) of lipase activity was defined as the amount of enzyme that catalyzed the release of $1 \mu \mathrm{mol}$ of fatty acids per mL. The test was performed in triplicate.

\subsubsection{Acidification Capacity}

LAB acidification capacity was assessed in sterile reconstituted skim milk. More accurately, $10 \mathrm{~mL}$ of sterile skim milk was inoculated with overnight bacterial cultures and incubated at $30^{\circ} \mathrm{C}$ for $24 \mathrm{~h}$. The $\mathrm{pH}$ changes were assessed with a pH meter (WTW, Weilheim, Germany). The acidification capacity was calculated as $\Delta \mathrm{pH}=\mathrm{pH}_{24 \mathrm{~h}}-\mathrm{pH}_{\text {initial }}$. The test was performed in triplicate.

\subsubsection{Antimicrobial Activity}

The antimicrobial activity of the lactic acid bacteria isolates was carried out with the well diffusion assay according to Drosinos et al. [9]. In brief, cell-free supernatant was obtained from overnight bacterial cultures, neutralized, treated with catalase, and added to the wells that were punched in freshly prepared lawns containing a mixture of 5 strains of L. monocytogenes, E. coli O157:H7 and Salmonella sp. [11,12]. Growth inhibition exceeding $5 \mathrm{~mm}$ around the wells was used as an indicator of antimicrobial activity of the supernatant applied. The test was performed in triplicate.

\subsection{Analytical Methods}

Sugars were quantified according to DuBois et al. [13]. The $\mathrm{pH}$ was measured by a Metrohm $744 \mathrm{pH}$ meter. Ethanol and acetic acid were quantified via HPLC-RI (Shodex) with an Aminex HPX-87H column (Biorad) at $60^{\circ} \mathrm{C}$ and a cation $\mathrm{H}$ micro-guard cartridge (Biorad), with $\mathrm{H}_{2} \mathrm{SO}_{4} 0.006 \mathrm{~N}$ as mobile phase at a flow rate of $0.7 \mathrm{~mL} / \mathrm{min}$. Lactic acid was quantified spectrophotometrically at $340 \mathrm{~nm}$ using a D-/L-Lactic Acid Assay Kit (Megazyme). The test was performed in triplicate.

\section{Results}

\subsection{Fermentation Tests}

Table 1 summarizes the results of fermentation of the three sugary substrates that were tested in this study. The main difference among substrates is the initial $\mathrm{pH}$ of the cultures, which was neutral for BSS and quite acidic for SCN and NAJ and the initial concentration of sugar, which was much higher for the juices. As shown, in the case of BSS, $80 \%$ of the sugar content was fermented whereas in the cases of SCN and NAJ the uptake of sugars was less than $50 \%$. The distribution of the fermentative products were similar with ethanol being the prominent final product, reaching maximum concentration of $2.14 \pm 0.12 \%(\mathrm{v} / \mathrm{v})$ for SCN. Lactate was also detected in all three beverages in similar concentrations, whereas the presence of acetic acid was not detected.

Table 1. Change of the $\mathrm{pH}$ value, carbohydrate consumption and metabolite production after $24 \mathrm{~h}$ fermentation at $25^{\circ} \mathrm{C}$ of the three sugary substrates employed in this study.

\begin{tabular}{|c|c|c|c|c|c|c|c|}
\hline Substrate & $\mathrm{pH}_{0}$ & $\mathrm{pH}_{\mathrm{f}}$ & $\begin{array}{c}S_{0} \text { Sugars } \\
(\%, w / v)\end{array}$ & $\begin{array}{c}\mathrm{S}_{\mathrm{f}} \text { Sugars } \\
(\%, \mathrm{w} / \mathrm{v})\end{array}$ & $\begin{array}{l}\text { Ethanol } \\
(\%, v / v)\end{array}$ & $\begin{array}{c}\text { Lactic Acid } \\
(\%, w / v)\end{array}$ & $\begin{array}{l}\text { Acetic Acid } \\
(\mathrm{mg} / \mathrm{L})\end{array}$ \\
\hline BSS & $6.9 \pm 0.01$ & $4.1 \pm 0.01$ & $5.03 \pm 0.2$ & $0.93 \pm 0.11$ & $1.96 \pm 0.11$ & $162.12 \pm 12.09$ & nd \\
\hline SCN & $3.9 \pm 0.01$ & $3.5 \pm 0.02$ & $13.2 \pm 0.2$ & $8.92 \pm 0.1$ & $2.14 \pm 0.12$ & $148.35 \pm 9.46$ & nd \\
\hline NAJ & $4 \pm 0.01$ & $3.7 \pm 0.01$ & $9.2 \pm 0.1$ & $6.96 \pm 0.1$ & $0.85 \pm 0.04$ & $134.13 \pm 8.78$ & nd \\
\hline
\end{tabular}

nd: not detected.

\subsection{Yeast and Bacterial Enumeration in Kefir Grains}

Bacterial and yeast populations were enumerated in BSS, NAJ and SCN kefir grains at 4.32, 4.85 and $4.34 \log \mathrm{CFU} / \mathrm{g}$, and at 6.28, 6.58, and $6.41 \log \mathrm{CFU} / \mathrm{g}$, respectively. 
A total of 50 bacterial and 83 yeast isolates were obtained, subjected to RAPD-PCR analysis and effectively separated into several clusters (Figures 1 and 2). More accurately, bacteria were separated into five clusters, designated I to V (Figure 1). The majority of the clusters contained isolates from the same kefir sample with the exception of clusters II and III, which consisted of isolates from apple (NAJ) and cherry (SCN) kefir samples. One to three representative isolates from each cluster were subjected to sequencing of the V1-V3 region of the 16S rRNA gene and the resulting phylogenetic affiliation is exhibited in Table 2. Similarly, yeasts were separated into seven clusters, defined I to VII (Figure 2). The clusters involved yeast isolates from more than one sugary kefir grains, apart from cluster IV, which comprised of isolates from apple (NAJ) kefir sample.

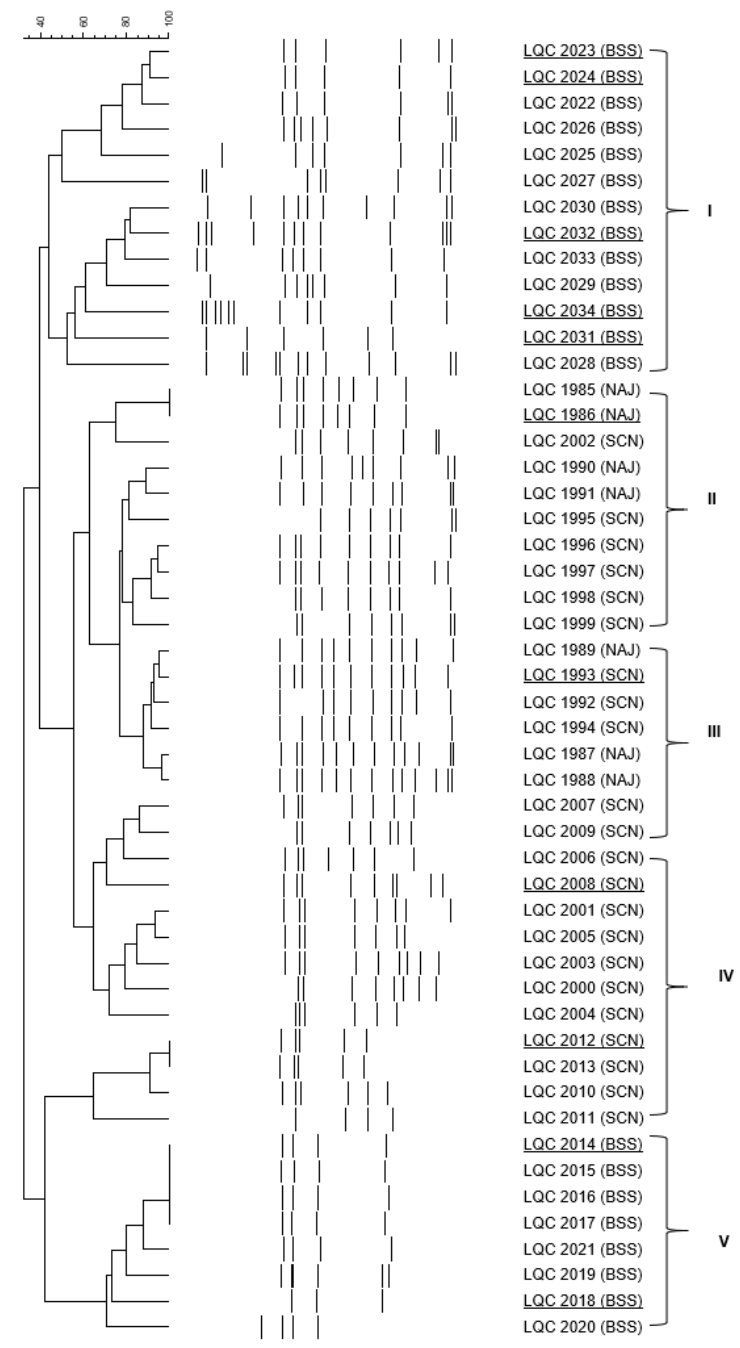

Figure 1. Cluster analysis of RAPD-PCR patterns of bacterial isolates, obtained from apple (NAJ), cherry (SCN) and sugary water (BSS) kefir grains. Distance is indicated by the mean correlation coefficient $[\mathrm{r}(\%)]$ and clustering was performed by UPGMA analysis. The representative strains selected for 16S rRNA gene sequencing are underlined. Latin numerals designate bacterial species (I, and V: Lb. rhamnosus, II, III and IV: B. amyloliquefaciens). 

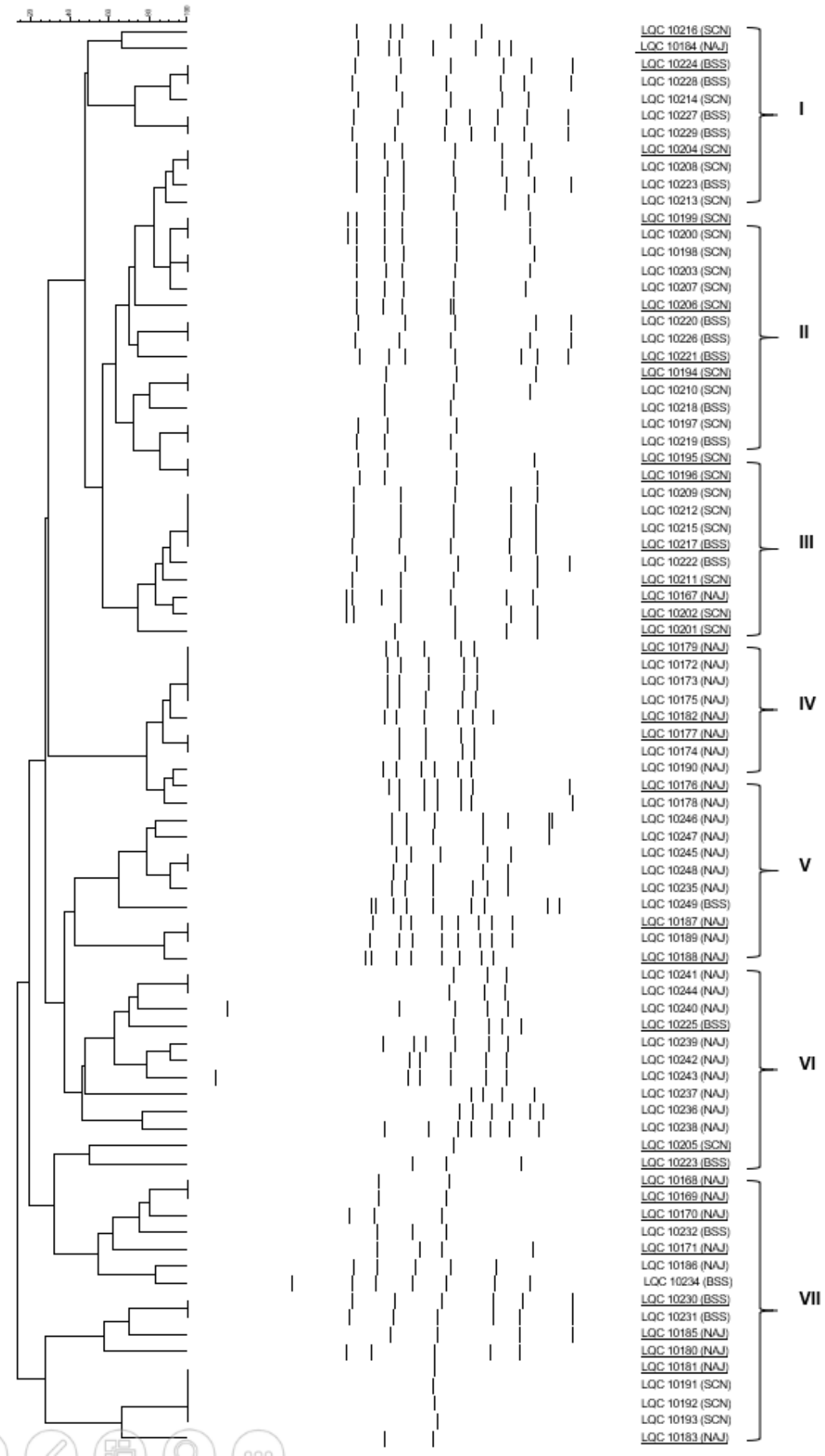

Figure 2. Cluster analysis of RAPD-PCR patterns of yeast isolates, obtained from apple (NJA), cherry (SCN) and sugary water (BSS) kefir grains. Distance is indicated by the mean correlation coefficient $[\mathrm{r}(\%)]$ and clustering was performed by UPGMA analysis. The representative strains selected for $26 \mathrm{~S}$ rRNA gene sequencing are underlined. Latin numerals designate yeast species (I, II, III, VI and VII: S. cerevisiae, IV and V: K. marxianus). 
Table 2. Phylogenetic position of yeast and bacterial strains based on sequencing of the D1/D2 region of 26S-and V1-V3 region of 16S rRNA gene, respectively.

\begin{tabular}{|c|c|c|c|c|}
\hline & Strain Number & Closest Relative & Identity (\%) & $\begin{array}{c}\text { Accession } \\
\text { Number }\end{array}$ \\
\hline \multirow{32}{*}{ Yeasts } & LQC 10194 & S. cerevisiae & 99 & MG017543.1 \\
\hline & LQC 10195 & S. cerevisiae & 99 & MG017587.1 \\
\hline & LQC 10196 & S. cerevisiae & 99 & MG017572.1 \\
\hline & LQC 10199 & S. cerevisiae & 99 & MG017572.1 \\
\hline & LQ̄C 10201 & S. cerevisiae & 99 & MG017587.1 \\
\hline & LQC 10202 & S. cerevisiae & 99 & MG017588.1 \\
\hline & LQC 10204 & S. cerevisiae & 99 & MG017572.1 \\
\hline & LQC 10205 & S. cerevisiae & 100 & JQ964228.1 \\
\hline & LQC 10206 & S. cerevisiae & 100 & MG017572.1 \\
\hline & LQC 10211 & S. cerevisiae & 100 & MF406146.1 \\
\hline & LQC 10216 & S. cerevisiae & 100 & KR069090.1 \\
\hline & LQ̄C 10167 & S. cerevisiae & 100 & MG017572.1 \\
\hline & LQC 10168 & S. cerevisiae & 99 & JQ964228.1 \\
\hline & LQC 10170 & S. cerevisiae & 100 & MF406146.1 \\
\hline & LQC 10171 & S. cerevisiae & 100 & MF406146.1 \\
\hline & LQ̄C 10176 & S. cerevisiae & 99 & KJ660850.1 \\
\hline & LQC 10177 & K. marxianus & 99 & KJ491106.1 \\
\hline & LQC 10179 & K. marxianus & 99 & KJ491106.1 \\
\hline & LQC 10180 & K. marxianus & 100 & KJ491106.1 \\
\hline & LQC 10181 & S. cerevisiae & 100 & MF406146.1 \\
\hline & LQC 10182 & K. marxianus & 100 & MH244202.1 \\
\hline & LQC 10183 & S. cerevisiae & 100 & KJ660848.1 \\
\hline & LQC 10184 & S. cerevisiae & 100 & MG017572.1 \\
\hline & LQC 10185 & S. cerevisiae & 99 & MF406146.1 \\
\hline & LQC 10187 & K. marxianus & 99 & KJ491106.1 \\
\hline & LQC 10188 & K. marxianus & 100 & FJ896141.1 \\
\hline & LQC 10217 & S. cerevisiae & 100 & MG017572.1 \\
\hline & LQC 10221 & S. cerevisiae & 99 & MG017572.1 \\
\hline & LQ̄C 10224 & S. cerevisiae & 100 & MG017587.1 \\
\hline & LQC 10225 & S. cerevisiae & 99 & MG017585.1 \\
\hline & LQC 10230 & S. cerevisiae & 100 & MF406146.1 \\
\hline & LQC 10233 & S. cerevisiae & 100 & MF406146.1 \\
\hline \multirow{11}{*}{ Bacteria } & LQC 1986 & B. amyloliquefaciens & 99 & KY392912.1 \\
\hline & LQC 1993 & B. amyloliquefaciens & 98 & MH045777.1 \\
\hline & LQC 2012 & B. amyloliquefaciens & 99 & KY072769.1 \\
\hline & LQC 2014 & Lb. rhamnosus & 99 & СР020464.1 \\
\hline & LQC 2018 & Lb. rhamnosus & 100 & HQ774719.1 \\
\hline & LQC 2023 & Lb. rhamnosus & 99 & СР020464.1 \\
\hline & LQC 2024 & Lb. rhamnosus & 99 & СР020464.1 \\
\hline & LQC 2031 & Lb. rhamnosus & 99 & LC333198.1 \\
\hline & LQC 2032 & Lb. rhamnosus & 99 & LC333198.1 \\
\hline & LQC 2034 & Lb. rhamnosus & 99 & LC333198.1 \\
\hline & LQC 2008 & B. amyloliquefaciens & 99 & MF953984.1 \\
\hline
\end{tabular}

The majority of bacterial isolates ( 29 of 50) were identified as Bacillus amyloliquefaciens, while the rest 21 were classified as Lactobacillus rhamnosus. Regarding yeasts, the majority of the isolates (64 of 83) were identified as Saccharomyces cerevisiae while the remaining 19 were classified as Kluyveromyces marxianus.

Regarding the bacterial and yeast microecosystem composition of the BSS, NAJ and SCN kefir samples, a total of 50 bacterial isolates were obtained, 7 of which were retrieved from NAJ, 22 from $\mathrm{SCN}$, and 21 from BSS kefir grains. B. amyloliquefaciens was the only species isolated from NAJ and SCN kefir grains; on the contrary, Lb. rhamnosus was the only species isolated from BSS kefir grains. As far as yeasts were concerned, a total of 83 yeast isolates were obtained; 38 from NAJ, 26 from SCN, and 19 
from BSS kefir grains. S. cerevisiae was the only species isolated from SCN kefir grains. A consortium consisting of S. cerevisiae and K. marxianus was evident in BSS and NAJ kefir grains; in the first case $94.7 \%$ of the isolates were assigned to $S$. cerevisiae and the remaining $5.3 \%$ to K. marxianus. Regarding the yeast microbiota of NAJ kefir grains, it consisted of S. cerevisiae (55.3\%) and K. marxianus (44.7\%).

\subsection{Assessment of Technological Properties}

\subsubsection{Proteolytic Activity}

The agar well diffusion assay was performed for 50 bacterial and 83 yeasts isolates and those that provided with positive results were further analyzed by sodium dodecyl sulfate polyacrylamide gel electrophoresis (SDS-PAGE). In the first case, a clear zone of casein hydrolysis, around the wells, indicated the presence of proteolytic activity. The agar plate assay revealed that 4 bacterial and 9 yeast isolates were proteolytic. Regarding the bacterial isolates, three were identified as $\mathrm{Lb}$. rhamnosus (LQC 2014, 2015, 2030) and one as B. amyloliquefaciens (LQC 1990) and originated from BSS and NAJ kefir grains, respectively. As far as yeasts were concerned, three S. cerevisiae (LQC 10184, 10235, 10237) and six K. marxianus isolates (LQC 10179, 10182, 10245, 10246, 10247, 10248) were found proteolytic, all originating from NAJ kefir grains. Then, SDS-PAGE electrophoresis was performed on the positively indicated proteolytic isolates. The protein patterns of the uninoculated broth serving as a blank solution and the ones inoculated with microbial isolates were identical. More accurately, the protein bands corresponding to caseins as 1 , as $2, \beta$, and $\mathrm{k}$, with molecular weights $23,25,24$, and $19 \mathrm{kDa}$, respectively, were clearly visible in all samples, including the blank, indicating absence or partial hydrolysis.

\subsubsection{Lipolytic Activity}

A total of 50 bacterial and 83 yeast isolates were tested for lipase secretion, by employing a screening technique on agar plates and a subsequent titrimetric analysis, for those assessed as lipolytic. According to the agar plate assay 40 bacterial isolates appeared to possess lipolytic activity, 29 of which were identified as B. amyloliquefaciens and the rest 11 as Lb. rhamnosus. As far as yeasts were concerned, 45 isolates were revealed to possess lipolytic capacity, 29 were assigned to S. cerevisiae, and 16 to K. marxianus. Those having exhibited lipolytic activity were tested for lipase production in liquid medium containing tributyrine and lecithin as emulsifier. The results in $\mathrm{AU} / \mathrm{mL}$ are presented in Figures 3 and 4 for yeasts and bacteria, respectively. Bacterial isolates showing the highest lipase activity were B. amyloliquefaciens LQC 1990 and Lb. rhamnosus LQC 2023 (10.50 and 10.05 AU/mL, respectively), originating from NAJ and BSS kefir grains, respectively. Bacterial isolates from SCN kefir grains displayed the lowest lipase activity, with the values ranging from 1.05 to $5 \mathrm{AU} / \mathrm{mL}$. Yeast strains retrieved from NAJ and SCN kefir grains presented both, the highest and lowest lipase capabilities. In other words, yeast isolates S. cerevisiae LQC 10237 and LQC 10186, originating from NAJ kefir grains, exhibited lipase activities of 20.85 and $1.05 \mathrm{AU} / \mathrm{mL}$, respectively. Similarly, yeast isolates S. cerevisiae LQC 10199 and LQC 10198, which were obtained from SCN kefir grains, showed lipase activities of 16.05 and $1.45 \mathrm{AU} / \mathrm{mL}$, respectively. 


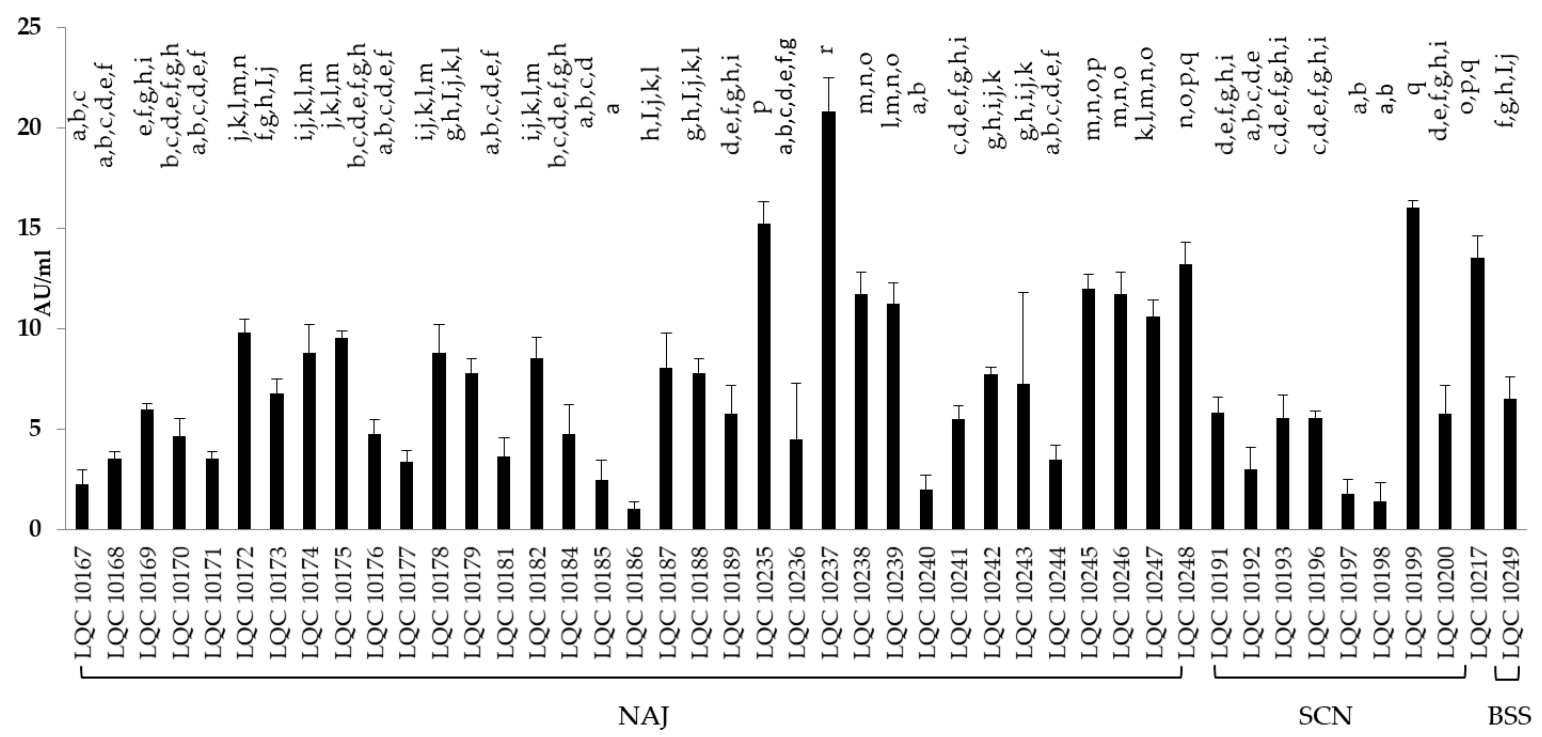

Figure 3. Lipase activity in $\mathrm{AU} / \mathrm{mL}$ of the yeast isolates. Different letters (a-r) indicate statistically significant differences $(p<0.05)$.

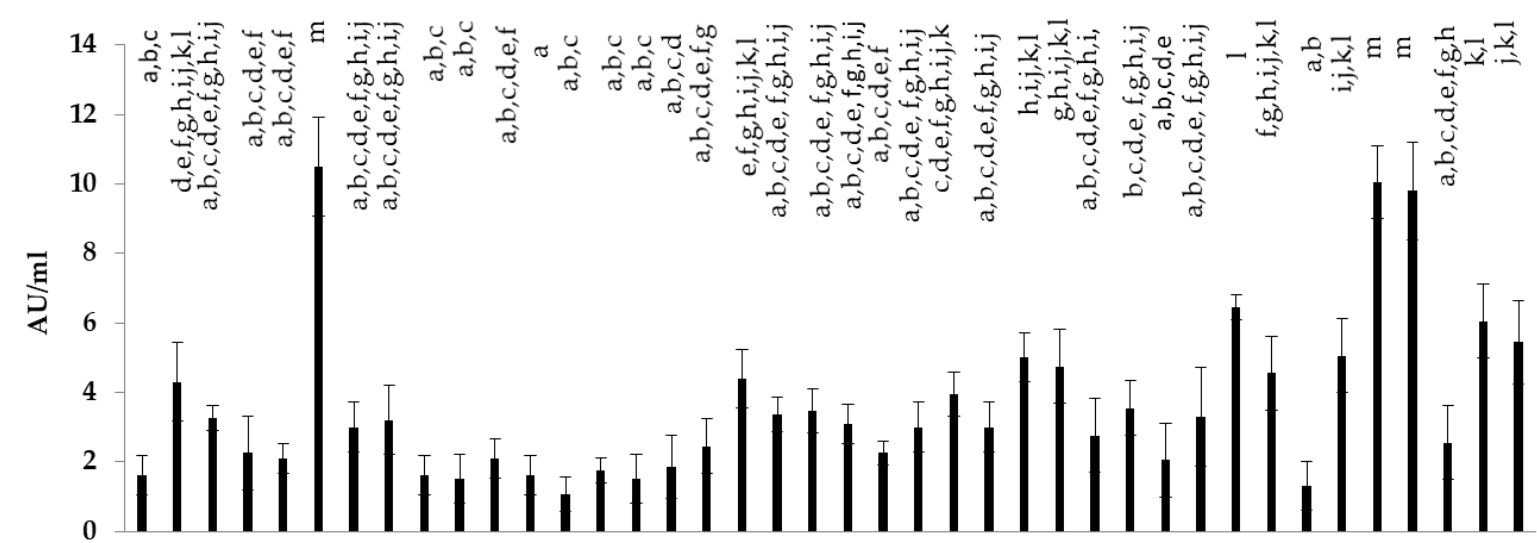

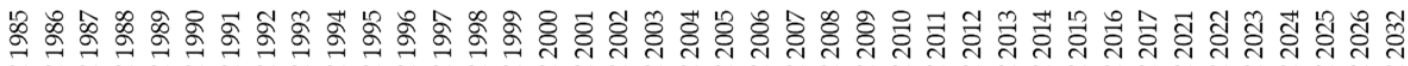

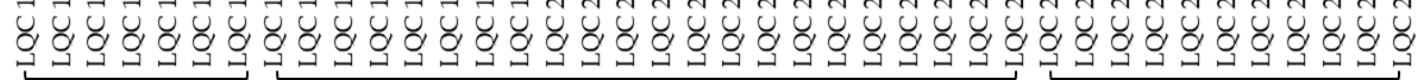

NAJ

SCN

BSS

Figure 4. Lipase activity in $\mathrm{AU} / \mathrm{mL}$ of the bacterial isolates. Different letters (a-m) indicate statistically significant differences $(p<0.05)$.

\subsubsection{Acidification Capacity}

The acidification capacity of the bacterial isolates after $24 \mathrm{~h}$ of incubation in reconstituted skim milk, is exhibited in Figure 5. The most prominent acidification, with $\Delta \mathrm{pH}$ ranging between 0.78 and $1.07 \mathrm{pH}$ units, was displayed by the 21 isolates identified as Lb. rhamnosus. In particular, two Lb. rhamnosus isolates, namely LQC 2018 and LQC 2022, achieved the highest acidifying capacity, with a $\Delta \mathrm{pH}$ of 1.06 and 1.07, respectively. In contrast, the 29 B. amyloliquefaciens isolates, showed significantly $(p<0.05)$ lower acidifying activity, with $\Delta \mathrm{pH}$ values, ranging between $0.12-0.28 \mathrm{pH}$ units. 


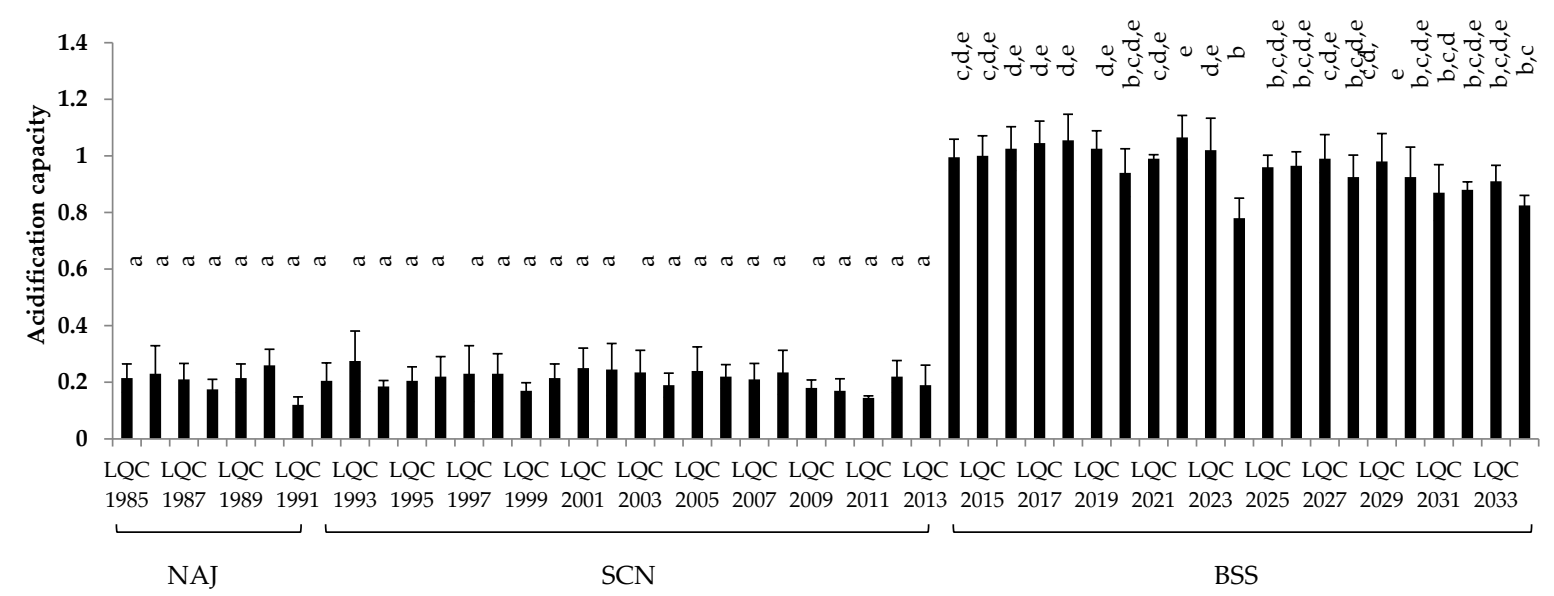

Figure 5. Acidification capacity of the bacterial isolates after $24 \mathrm{~h}$ of incubation in reconstituted skim milk. Different letters (a-e) indicate statistically significant differences $(p<0.05)$.

\subsubsection{Antimicrobial Activity}

A total of 50 bacterial isolates were screened for the production of antimicrobial compounds against a mixture of 5 strains of L. monocytogenes, E. coli O157:H7 and Salmonella sp. No such activity was detected.

\section{Discussion}

In general, the results obtained in the present study regarding the carbohydrate consumption and the metabolite production of BSS, SCN and NAJ are in good agreement with previous studies on sugary kefir beverages, according to which ethanol is the main metabolic product followed by lactate and acetate and in some cases citrate [3]. In the present study citric acid was not quantified but according to the mass balances of sugars to metabolites conversion the presence of other metabolites should indeed be expected. Differences in the final concentrations could be attributed to differences in the microbial consortia but also to the fermentation conditions. For instance, in the study of Randazzo et al. [14], in which the production of kefir beverages from different fresh fruit juices was investigated, higher ethanol concentrations (up to $4.96 \%, \mathrm{v} / \mathrm{v}$ ) were reported and also acetate detection was noted in similar concentrations with lactate. It should be noted that Randazzo et al. [14] performed backslopping inoculation instead of direct fermentation via water kefir grains whereas fermentation lasted $48 \mathrm{~h}$ and as such sugar consumption was much higher. In the present study fermentations were ceased after $24 \mathrm{~h}$, and consequently lower consumption of carbohydrates and lower concentration of fermentation products were indeed expected.

Previous studies have demonstrated the microbial complexity of sugary kefir grains, mainly composed of LAB, namely Lactobacillus spp., Lactococcus spp., Leuconostoc spp. and Streptococcus spp., yeasts, including Saccharomyces spp., Kluyveromyces spp. and Candida spp. and occasionally acetic acid bacteria. The diverse microbial profile of sugary kefir grains has been attributed to the various geographical regions of the grain preparation and the fermentation conditions $[2,3,5,14]$.

In general, LAB population has been reported to exceed that of yeasts in both milk and sugary kefir grains $[1,2,5]$. However, there are studies that have either reported similar populations or exhibited the exact opposite, i.e., dominance of yeast population over LAB [15]. The latter was also the case in the present study; yeasts population exceeded the one of LAB by $2 \log C F U / g$. This can be attributed to the increased sugar concentration due to the gradual replacement of milk with brown sugar solution enriched with plums (BSS) and then apple (NAJ) and cherry juice (SCN).

In the present study, S. cerevisiae was present in all three sugary kefir grains as the predominant yeast, while K. marxianus formed a secondary microbiota in two out of three sugary kefir grains, namely BSS and NAJ kefir grains. Regarding $S$. cerevisiae, these findings are in agreement with previous 
studies $[3,5,6,16]$, which confirmed the high prevalence of this yeast species in sugary kefir grains. On the other hand, although K. marxianus presence in sugary kefir grains has been previously reported [16], this yeast is isolated from milk kefir grains more frequently as part of the secondary microbiota [17]. Compared to S. cerevisiae, which cannot ferment lactose, K. marxianus, a lactose-fermenting yeast, may possess a comparative advantage in milk-based substrates. However, in sugary solutions, S. cerevisiae converts sucrose into glucose and fructose, and in milk substrates presence of other microbial species that convert lactose into glucose and galactose may favor its dominance [3]. The presence of both S. cerevisiae and K. marxianus in Tibetan kefir grains was previously demonstrated by Lu et al. [17], who reported S. cerevisiae predominance over time, due to its adaptation to low $\mathrm{pH}$, ability to survive with or without oxygen and its alcohol tolerance. As for K. marxianus, the necessity for oxygen uptake and the antagonistic relationship with S. cerevisiae contributed to its decrease over time. Despite the predominant character of S. cerevisiae in various sugary kefir grains, Gulitz et al. [2] after employing PCR-RAPD analysis and $16 \mathrm{~S}$ rRNA gene sequencing, reported S. cerevisiae presence as secondary yeast biota in water kefir grains, originating from different regions, while the majority of yeast isolates were identified as Zygotorulaspora florentina. Thus, the geographical origin of the kefir grains seems to determine the microbial profile revealed.

As for bacterial isolates, those originating from NAJ and SCN kefir grains were identified as B. amyloliquefaciens, while the ones from BSS kefir grains were classified as Lb. rhamnosus. B. amyloliquefaciens presence in any type of sugary or milk kefir grains has not been reported so far. On the other hand, presence of $L b$. rhamnosus in Thai sugary kefir grains and beverage has been reported by Sarikkha et al. [6]. However, Lb. rhamnosus was identified with less than $97 \%$ similarity, compared to those of B. cereus and Gluconobacter japonicus, ranging from $99 \%$ to $100 \%$, respectively.

The presence of Lactobacillus spp., Lactococcus spp. and Leuconostoc spp. in sugary kefir grains has been previously reported. Dominance of $L b$. hordei and $L b$. nagelii and a secondary microbiota consisting of Ln. mesenteroides and Ln. citreum in sugary kefir grains, was reported by Gulitz et al. [2]. Hsieh et al. [18] used a combined approach of culture-dependent and -independent methods and reported the dominance of $L n$. mesenteroides in kefir grains fermented with brown sugar, followed by $L b$. hordei and $L b$. mali at lower levels. Isolation of $L b$. kefiri, Lb. kefiranofaciens and Ln. mesenteroides from milk kefir grains, as well as $\mathrm{Lb}$. perolens, $\mathrm{Lb}$. parafarraginis, Lb. diolivorans, and Oenococcus oeni from sugary kefir grains was reported by Zanirati et al. [19]. The microbial complexity of sugary kefir grains was also demonstrated by Magalhães et al. [5], reporting Lb. paracasei as the predominant species, accompanied by a secondary microbiota consisting of Acetobacter lovaniensis, Lb. parabuchneri, Lb. kefiri, and Lactococcus lactis.

B. amyloliquefaciens is a phylogenetically close relative of $B$. subtilis, whose presence has been verified via phenotypic and genotypic approaches from Tibetan kefir grains [20]. Both B. subtilis and B. amyloliquefaciens species, are often isolated from fermented soy products [21], dairy products [22] and soil as well [23]. Their antibiotic and antimicrobial activity as well as probiotic potential have also been studied [24]. Interestingly, Kort et al. [25] reported that the microbial consortium of S. thermophilus $\mathrm{C} 106$ and $\mathrm{Lb}$. rhamnosus yoba 2012 was based on the proteolytic character of the former and its capacity to digest lactose and casein, thus aiding the latter to grow in milk substrates. B. amyloliquefaciens has also been reported as one of the most potent producer of extracellular proteases [21], whose interaction with $\mathrm{Lb}$. rhamnosus could probably overcome the limitations highlighted by Kort et al. [25] and Parker et al. [26].

Acidifying capacity constitutes a determining test for the selection of bacterial strains as starter cultures in dairy fermentations. In our study Lb. rhamnosus isolates exhibited higher capacity than B. amyloliquefaciens strains. Despite the fact that $L b$. rhamnosus isolates are not preferred as primary starter cultures in the dairy industry, this species involves some extremely interesting strains, such as Lb. rhamnosus GG, whose probiotic potential has been extensively studied [27]. In a study by Ayad et al. [28] Lb. rhamnosus acidifying activity was characterized as slow, since it is grouped with facultative heterofermentative lactobacilli. In agreement with these results, Sodini et al. [29] confirmed 
its poor acidification activity, by reporting that more than $20 \mathrm{~h}$ were needed for $L b$. rhamnosus to reach $\mathrm{pH}$ 5.0. In contrast Marroki et al. [30] reported two fast acidifying Lb. rhamnosus strains, which showed values of $\Delta \mathrm{pH} 0.63$ and $0.69 \mathrm{pH}$ units after $6 \mathrm{~h}$, as well as 1.87 and $1.96 \mathrm{pH}$ units after $24 \mathrm{~h}$. As for B. amyloliquefaciens, although its probiotic potential has been investigated [21], its acidifying capacity has not been thoroughly assessed.

Proteolysis is considered as one of the most important technological properties, actively participating in texture and flavor development of fermented products. Proteolytic activity of LAB has been studied for a variety of dry fermented meat products during the ripening process [31], dairy products [32] and sourdoughs [33]. In the present study, the initial screening with agar well diffusion assay revealed four proteolytic bacterial isolates, three of which were identified as Lb. rhamnosus and one as B. amyloliquefaciens, as well as nine proteolytic yeast isolates, three of which were identified as S. cerevisiae and six as K. marxianus. However, further analysis by SDS-PAGE revealed no difference in the protein profiles between the uninoculated samples, serving as control, and the ones inoculated with the microbial isolates. Similar results were reported by Kirilov et al. [34] and Dallas et al. [35]. In both studies, the inability of SDS-PAGE to properly depict caseinolytic activity was highlighted and longer incubation times were suggested. On the other hand, SDS-PAGE, applied on LAB isolated from dairy products, after the initial proteolytic screening by an agar well diffusion method, revealed the presence of 3 highly proteolytic isolates identified as Enterococcus faecalis (strains FT132 \& FT522) and Lb. paracasei FT700 [36]. SDS-PAGE analysis confirmed their proteolytic capacity, showing the degradation of a-and $\beta$-caseins, as well as $\beta$-lactoglobulin and $\alpha$-lactalbumin. In agreement with these findings, El-Ghaish et al. [37] using an agar well diffusion assay, as a screening proteolytic method on lactococci isolated from Egyptian dairy products, followed by further analysis by SDS-PAGE, reported six highly proteolytic isolates, four identified as E. faecalis and two as E. faecium. The proteolytic capacity of Lb. rhamnosus $[38,39]$ as well as B. amyloliquefaciens [40-42] have been studied to some extent. In the first case, Moslehishad et al. [38] demonstrated the high protease capacity of Lb. rhamnosus PTCC 1637 in fermented cow and camel milk. In addition, the presence of probiotic cultures Lb. rhamnosus HN001 and $\mathrm{Lb}$. acidophilus NCFM enhanced proteolysis in Edam cheese [39].

Bacillus species produce a wide range of extracellular and intracellular proteases, with subtilisins, a family of alkaline serine endoproteases, being the most extensively studied ones. The extracellular protease capacity is mainly attributed to an alkaline serine protease (subtilisin) and a neutral metalloprotease, while less than $1 \%$ to an esterase. As for intracellular proteases, at least two homologous genes have been reported in the genome of B. subtilis coding for serine proteases, intracellular serine protease and secretory subtilisin [43]. Samad et al. [42] reported the protease production by B. amyloliquefaciens B7, originating from fermented fish sauce and its purification with the use of an aqueous two-phase system (ATPS). Wang et al. [40] reported the cloning of a neutral protease encoding gene, Banpr, from B. amyloliquefaciens strain K11. Finally, high protease activity of B. amyloliquefaciens UEF01 endophytic to carnivorous plant Utricularia exoleta R. Br. was also demonstrated by Chaudhuri et al. [41], with the enzyme sharing similarities with alkaline proteases, previously isolated from B. amyloliquefaciens.

As far as yeasts were concerned, they constitute an extremely diverse group, with significant contribution to the formation of aroma and flavor precursors, during fermentation and maturation processes. Their ability to degrade residual lactose, lactate utilization, symbiosis with $\mathrm{LAB}$, and their protein hydrolytic capacity necessitate their use as adjunct microbiota in the production of fermented dairy products. The proteolytic intracellular system of S. cerevisiae includes three categories of proteases, cytosolic proteasome, vacuolar proteases, and finally proteases within the secretory pathway [44]. Several studies have reported the poor proteolytic capacity of S. cerevisiae strains [45]. On the other hand, Klein et al. [46] reported that some yeast isolates, including S. cerevisiae, showed greater peptidase capacity compared to most bacterial species and were more capable of hydrolyzing $\beta$-casein phosphorylated peptides. The degradation of as1 and $\beta$-casein components of the S. cerevisiae FB7, isolated from blue veined cheeses, has also been stated [47]. Finally, Seredyński et al. [48] reported 
that S. cerevisiae strains secreted diverse proteases, depending on the availability and quality of the protein substrate.

K. marxianus, an interesting yeast in biotechnology, has been regularly isolated from dairy products due to its ability to assimilate a wide range of sugars, such as lactose. Beniwal et al. [49] reported K. marxianus 6C17 ability to hydrolyze galactose into ethanol, thus verifying its variability in sugar fermentation and thereby its alignment with Crabtree-positive yeasts. However, little is known about its proteolytic capacity. Ramírez-Zavala et al. [50] demonstrated the presence of a K. marxianus-derived serine-carboxypeptidase, an exopeptidase, hydrolyzing C-terminal amino acids from peptides and proteins and proposed its usage as substitute for animal-originating enzymes in food industry. They also reported the isolation of a lysine aminopeptidase, originating from K. marxianus, which catalyzed the removal of $n$-terminal alkaline residues, mainly lysine. Its strong suppression by bestatin, o-phenanthroline and EDTA, has led to its characterization as a metalloprotease.

Lipolysis, the hydrolysis of triacylglycerols to free fatty acids (FFA) mono- and diglycerides, has been attributed to the presence of lipases and esterases, with the former hydrolyzing esters of longer chain fatty acids, FA, and the latter preferentially acting on esters of shorter chain FFA [51]. Further FFA catabolism leads to the production of impact-aromatic compounds, namely esters, methylketones, lactones and secondary alcohols. Lipolysis in fermented meat products, such as dry-fermented sausages, has been partly attributed to members of Staphylococcus genus and partly to muscle and fat tissue enzymes and is essential for the development of dry-cured sausage flavor [52]. Lipolysis during cheese ripening has also been studied by many authors [53]. However, milk fat lipolysis does not happen in a great range of circumstances, which is the reason why many authors have focused on studying the proteolysis and FFA catabolism, as determining factors for the formation of aroma compounds. Lipolysis has been investigated in fermented products, such as wine [54] and fermented olives [55]. In our study, the lipolytic activity was initially assessed by a screening agar well diffusion assay and further by quantitative evaluation of the lipase activity, a procedure that has been also applied previously [10]. Seven B. amyloliquefaciens and $33 \mathrm{Lb}$. rhamnosus isolates as well as 29 S. cerevisiae and $16 \mathrm{~K}$. marxianus isolates showed halos around the well and were further analyzed with titrimetric assay. The bacterial strains with the highest lipase activity were LQC $1990(10.50 \mathrm{AU} / \mathrm{mL})$ and 2023 (10.05 AU/mL), identified as B. amyloliquefaciens and Lb. rhamnosus, respectively. The best lipase producing yeast isolates were LQC 10237 (20.85 AU/mL), 10199 (16.05 AU/mL), 10235 (15.25 AU/mL) and $10248(13.25 \mathrm{AU} / \mathrm{mL})$, the former two identified as S. cerevisiae and the latter as K. marxianus. At yeast level, S. cerevisiae and K. marxianus strains have been characterized as poor lipase producers $[54,55]$. Hansen \& Jakobsen [47] demonstrated that $S$. cerevisiae strains isolated from blue veined cheeses could ferment tributyrine and low chain FFA, but not C:14 FFA, thus indicating no lipase activity.

Few studies have elucidated the lipolytic system of K. marxianus. S. cerevisiae and K. marxianus lipolytic activity were investigated by Hernández et al. [56]. In that study the majority of the yeast strains were able to hydrolyze tributyrine, thus exhibiting esterase capability. However, less strains exhibited lipase activity when olive oil was used as substrate. In contrast, Cardoso et al. [57], studying the proteolytic and lipolytic profile of yeasts isolated from traditional Brazilian cheese, revealed that K. marxianus $83 \mathrm{~F}$ achieved the highest lipase capacity $(0.06 \pm 0.04 \mathrm{U} / \mathrm{mL})$, while K. marxianus $60 \mathrm{P}$ showed $\beta$-galactosidase activity.

As far as bacterial isolates were concerned, several authors have reported moderate to none lipolytic activity of $L b$. rhamnosus strains [58]. However extended ripening period, contributes to the hydrolysis of considerable amounts of FFA [59]. Weak lipolytic capacity constitutes a beneficial attribute for fermented food products, such as cheese, by inhibiting the development of bitter and rancid aroma-compounds. Falcinelli et al. [60] demonstrated that $L b$. rhamnosus administration caused transcriptional modifications in TGs biosynthesis associated genes, namely agpat4, dgat2, and fit 2 and probably induced lipolysis. An inhibition of agpat4 and dgat 2 transcription, and thus a decline in triglyceride capacity and a reduction of LD aggregation, stimulated by lower levels of fit 2 gene, showed the triggering of lipolysis by Lb. rhamnosus. 
Bacillus spp. is a well-known producer of valuable extracellular enzymes, such as lipases. In most cases, lipases are induced from lipidic carbon substrates, namely oils, fatty acids and glycerol. From an industrial point of view, lipase production is gaining much attention due to its use as cheap and versatile catalysts in biodiesel processing. Due to the rigid regulation of lipase synthesis, the cloning of lipase genes is often preferred. The first documentation of lipase gene from B. amyloliquefaciens cloning and application in biodiesel production was reported by Cai et al. [61]. B. amyloliquefaciens Nsic-8 lipase gene, lipBA, was isolated from a stinky tofu brine and successfully cloned in E. coli. Saengsanga et al. [62] also reported the cloning of another lip gene from B. amyloliquefaciens E1PA in E. coli and showed the affinity of the inducible alkaline E1PA lipase with wider range of substrates.

Bacteria may produce a wide variety of antimicrobial compounds, such as organic acids, ethanol, hydrogen peroxide and bacteriocins. The latter have been in the epicenter of intensive study over the last decades; knowledge on the factors that affect their production, their biochemical properties, as well as their applicability within the context of the hurdle theory, is constantly expanding [63]. The production of bacteriocins from $L b$. rhamnosus and B. amyloliquefaciens strains has been reported [64]. Bacteriocin production and sensitivity are strain-dependent properties [65]; the latter may partially explain their in situ limited use. In order to address this limitation, a mixture of strains is increasingly used in screening studies so that detection of antimicrobial compounds of broader range is facilitated. In the present study, no such compounds were detected.

In conclusion, according to the results obtained in the present study, dominance of yeast over bacterial population was evident in all sugary kefir samples assessed and attributed to the elevated carbohydrate concentration, compared to milk kefir. Regarding the technological properties of the isolates, Lb. rhamnosus strains LQC 2014 and 2015 that exhibited potent acidification capacity as well as proteolytic and lipolytic activities along with S. cerevisiae strains LQC 10184, 10235, and 10237 and K. marxianus strains LQC 10179, 10182, 10245, 10246, 10247, and 10248 that exhibited proteolytic and lipolytic activities are suitable candidates for the formation of the microbial consortium that is necessary to drive milk and sugary kefir fermentations.

Author Contributions: Conceptualization, M.P., I.N., S.P., E.H.D.; apply of analytical methods, M.K.S., I.N., S.P.; Writing-Original Draft Preparation, M.K.S., M.P., I.N., S.P., Review \& Editing M.K.S., M.P., I.N., S.P., E.H.D.

Funding: This research received no external funding.

Conflicts of Interest: The authors declare no conflict of interest.

\section{References}

1. Prado, M.R.; Blandón, L.M.; Vandenberghe, L.P.S.; Rodrigues, C.; Castro, G.R.; Thomaz-Soccol, V.; Soccol, C.R. Milk kefir: Composition, microbial cultures, biological activities, and related products. Front. Microbiol. 2015, 6, 422. [CrossRef] [PubMed]

2. Gulitz, A.; Stadie, J.; Wenning, M.; Ehrmann, M.A.; Vogel, R.F. The microbial diversity of water kefir. Int. J. Food Microbiol. 2011, 151, 284-288. [CrossRef] [PubMed]

3. Fiorda, F.A.; Pereira, G.V.D.M.; Thomaz-Soccol, V.; Rakshit, S.K.; Pagnoncelli, M.G.B.; Vandenberghe, L.P.D.S.; Soccol, C.R. Microbiological, biochemical, and functional aspects of sugary kefir fermentation-A review. Food Microbiol. 2017, 66, 86-95. [CrossRef] [PubMed]

4. Pidoux, M. The microbial flora of sugary kefir grain (the ginger beer plant): Biosynthesis of the grain from Lactobacillus hilgardii producing a polysaccharide gel. MIRCEN J. Appl. Microbiol. Biotechnol. 1989, 5, $223-238$. [CrossRef]

5. Magalhães, K.T.; Pereira, G.V.D.M.; Dias, D.R.; Schwan, R.F.; Pereira, G.V.M. Microbial communities and chemical changes during fermentation of sugary Brazilian kefir. World J. Microbiol. Biotechnol. 2010, 26, 1241-1250. [CrossRef]

6. Sarikkha, P.; Nitisoravut, R.; Poljungreed, I.; Boonyarattanakalin, S. Identification of bacteria and yeast communities in a Thai sugary kefir by polymerase chain reaction-denaturing gradient gel electrophoresis (PCR-DGGE) analyses. J. Ind. Technol. 2015, 11, 25-39. 
7. Doulgeraki, A.I.; Paramithiotis, S.; Kagkli, D.M.; Nychas, G.-J.E. Lactic acid bacteria population dynamics during minced beef storage under aerobic or modified atmosphere packaging conditions. Food Microbiol. 2010, 27, 1028-1034. [CrossRef]

8. Vogel, B.F.; Fussing, V.; Ojeniyi, B.; Gram, L.; Ahrens, P. High-Resolution Genotyping of Listeria monocytogenes by Fluorescent Amplified Fragment Length Polymorphism Analysis compared to Pulsed-Field Gel Electrophoresis, Random Amplified Polymorphic DNA Analysis, Ribotyping, and PCR-Restriction Fragment Length Polymorphism Analysis. J. Food Prot. 2004, 67, 1656-1665.

9. Drosinos, E.H.; Paramithiotis, S.; Kolovos, G.; Tsikouras, I.; Metaxopoulos, I. Phenotypic and technological diversity of lactic acid bacteria and staphylococci isolated from traditionally fermented sausages in Southern Greece. Food Microbiol. 2007, 24, 260-270. [CrossRef]

10. Kamzolova, S.V.; Morgunov, I.G.; Aurich, A.; Perevoznikova, O.A.; Shishkanova, N.V.; Stottmeister, U.U.; Finogenova, T.V. Lipase secretion and citric acid production in Yarrowia lipolytica yeast grown on animal and vegetable fat. Food Technol. Biotechnol. 2005, 43, 113-122.

11. Paramithiotis, S.; Grivokostopoulos, N.; Skandamis, P.N. Investigating the correlation of constitutive proteins with the growth limits of Salmonella enterica isolates from feeds in response to temperature, $\mathrm{pH}$, formic and lactic acid. Food Res. Int. 2013, 53, 291-296. [CrossRef]

12. Hadjilouka, A.; Mantzourani, K.S.; Katsarou, A.; Cavaiuolo, M.; Ferrante, A.; Paramithiotis, S.; Mataragas, M.; Drosinos, E.H. Estimation of Listeria monocytogenes and Escherichia coli O157:H7 Prevalence and levels in naturally contaminated rocket and cucumber samples by Deterministic and Stochastic Approaches. J. Food Prot. 2015, 78, 311-322. [CrossRef] [PubMed]

13. Dubois, M.; Gilles, K.A.; Hamilton, J.K.; Rebers, P.A.; Smith, F. Colorimetric method for determination of sugars and related substances. Anal. Chem. 1956, 28, 350-356. [CrossRef]

14. Randazzo, W.; Corona, O.; Guarcello, R.; Francesca, N.; Germanà, M.A.; Erten, H.; Moschetti, G.; Settanni, L. Development of new non-dairy beverages from Mediterranean fruit juices fermented with water kefir microorganisms. Food Microbiol. 2016, 54, 40-51. [CrossRef]

15. Witthuhn, R.C.; Schoeman, T.; Britz, T.J. Isolation and characterization of the microbial population of different South African kefir grains. Int. J. Dairy Technol. 2004, 57, 33-37. [CrossRef]

16. Miguel, M.; Cardoso, P.; Magalhães-Guedes, K.; Schwan, R. Identification and assessment of kefir yeast potential for sugar/ethanol-resistance. Braz. J. Microbiol. 2013, 44, 113-118. [CrossRef]

17. Lu, M.; Wang, X.; Sun, G.; Qin, B.; Xiao, J.; Yan, S.; Pan, Y.; Wang, Y. Fine structure of tibetan kefir grains and their yeast distribution, diversity, and shift. PLoS ONE 2014, 9, e101387. [CrossRef] [PubMed]

18. Hsieh, H.; Wang, S.; Chen, T.; Huang, Y.; Chen, M. Effects of cow's and goat's milk as fermentation media on the microbial ecology of sugary kefir grains. Int. J. Food Microbiol. 2012, 157, 73-81. [CrossRef]

19. Zanirati, D.F.; Abatemarco, M., Jr.; de Cicco Sandes, S.H.; Nicoli, J.R.; Cantini Nunes, A.; Neumann, E. Selection of lactic acid bacteria from Brazilian kefir grains for potential use as starter or probiotic cultures. Anaerobe 2015, 32, 70-76. [CrossRef]

20. Gao, J.; Gu, F.; Abdella, N.H.; Ruan, H.; He, G. Investigation on culturable microflora in tibetan kefir grains from different areas of china. J. Food Sci. 2012, 77, M425-M433. [CrossRef]

21. Lee, A.; Cheng, K.-C.; Liu, J.-R. Isolation and characterization of a Bacillus amyloliquefaciens strain with zearalenone removal ability and its probiotic potential. PLoS ONE 2017, 12, e0182220. [CrossRef] [PubMed]

22. Hanafy, A.M.; Al-Mutairi, A.A.; Al-Reedy, R.M.; Al-Garni, S.M. Phylogenetic affiliations of Bacillus amyloliquefaciens isolates produced by a bacteriocin-like substance in goat milk. J. Taibah Univ. Sci. 2016, 10, 631-641. [CrossRef]

23. Boottanun, P.; Potisap, C.; Hurdle, J.G.; Sermswan, R.W. Secondary metabolites from Bacillus amyloliquefaciens isolated from soil can kill Burkholderia pseudomallei. AMB Express 2017, 7, 16. [CrossRef] [PubMed]

24. Stein, T. Bacillus subtilis antibiotics: Structures, syntheses and specific functions. Mol. Microbiol. 2005, 56, 845-857. [CrossRef]

25. Kort, R.; Westerik, N.; Serrano, L.M.; Douillard, F.P.; Gottstein, W.; Mukisa, I.M.; Tuijn, C.J.; Basten, L.; Hafkamp, B.; Meijer, W.C.; et al. A novel consortium of Lactobacillus rhamnosus and Streptococcus thermophilus for increased access to functional fermented foods. Microb. Cell Factories 2015, 14, 195. [CrossRef] 
26. Parker, M.; Zobrist, S.; Donahue, C.; Edick, C.; Mansen, K.; Hassan Zade Nadjari, M.; Heerikhuisen, M.; Sybesma, W.; Molenaar, D.; Diallo, A.M.; et al. Naturally ermented milk from northern Senegal: Bacterial community composition and probiotic enrichment with Lactobacillus rhamnosus. Front. Microbiol. 2018, 21, 2218. [CrossRef]

27. Rajoka, M.S.R.; Mehwish, H.M.; Siddiq, M.; Haobin, Z.; Zhu, J.; Yan, L.; Shao, D.; Xu, X.; Shi, J. Identification, characterization, and probiotic potential of Lactobacillus rhamnosus isolated from human milk. LWT 2017, 84, 271-280. [CrossRef]

28. Ayad, E.; Nashat, S.; El-Sadek, N.; Metwaly, H.; El-Soda, M. Selection of wild lactic acid bacteria isolated from traditional Egyptian dairy products according to production and technological criteria. Food Microbiol. 2004, 21, 715-725. [CrossRef]

29. Sodini, I.; Lucas, A.; Oliveira, M.; Remeuf, F.; Corrieu, G. Effect of milk base and starter culture on acidification, texture, and probiotic cell counts in fermented milk processing. J. Dairy Sci. 2002, 85, 2479-2488. [CrossRef]

30. Marroki, A.; Zuñiga, M.; Kihal, M.; Martínez, G.P. Characterization of Lactobacillus from Algerian goat's milk based on phenotypic, 16S rDNA sequencing and their technological properties. Braz. J. Microbiol. 2011, 42, 158-171. [CrossRef]

31. Mora, L.; Gallego, M.; Escudero, E.; Reig, M.; Aristoy, M.-C.; Toldrá, F.; Soler, L.M. Small peptides hydrolysis in dry-cured meats. Int. J. Food Microbiol. 2015, 212, 9-15. [CrossRef] [PubMed]

32. Ebner, J.; Aşçı Arslan, A.; Fedorova, M.; Hoffmann, R.R.; Küçükçetin, A.; Pischetsrieder, M. Peptide profiling of bovine kefir reveals 236 unique peptides released from caseins during its production by starter culture or kefir grains. J. Proteom. 2015, 117, 41-57. [CrossRef] [PubMed]

33. Capuani, A.; Behr, J.; Vogel, R.F. Influence of lactic acid bacteria on redox status and on proteolytic activity of buckwheat (Fagopyrum esculentum Moench) sourdoughs. Int. J. Food Microbiol. 2013, 165, 148-155. [CrossRef] [PubMed]

34. Kirilov, N.; Petkova, T.; Atanasova, J.; Danova, S.; Iliev, I.; Popov, Y.; Haertle, T.; Ivanova, I.V. Proteolytic activity in lactic acid bacteria from Iraq, Armenia and Bulgaria. Biotechnol. Biotechnol. Equip. 2009, 23, 643-646. [CrossRef]

35. Dallas, D.C.; Citerne, F.; Tian, T.; Silva, V.L.M.; Kalanetra, K.M.; Frese, S.A.; Robinson, R.C.; Mills, D.A.; Barile, D. Peptidomic analysis reveals proteolytic activity of kefir microorganisms on bovine milk proteins. Food Chem. 2016, 197, 273-284. [CrossRef]

36. Tulini, F.L.; Hymery, N.; Haertlé, T.; Le Blay, G.; De Martinis, E.C.P. Screening for antimicrobial and proteolytic activities of lactic acid bacteria isolated from cow, buffalo and goat milk and cheeses marketed in the southeast region of Brazil. J. Dairy Res. 2016, 83, 115-124. [CrossRef]

37. El-Ghaish, S.; Dalgalarrondo, M.; Choiset, Y.; Sitohy, M.; Ivanova, I.; Haertlé, T.; Chobert, J.-M. Screening of strains of Lactococci isolated from Egyptian dairy products for their proteolytic activity. Food Chem. 2010, 120, 758-764. [CrossRef]

38. Moslehishad, M.; Mirdamadi, S.; Ehsani, M.R.; Ezzatpanah, H.; Moosavi-Movahedi, A.A. The proteolytic activity of selected lactic acid bacteria in fermenting cow's and camel's milk and the resultant sensory characteristics of the products. Int. J. Dairy Technol. 2013, 66, 279-285. [CrossRef]

39. Aljewicz, M.; Cichosz, G.; Nalepa, B.; Kowalska, M. Influence of the probiotic Lactobacillus acidophilus NCFM and Lactobacillus rhamnosus HN001 on proteolysis patterns of Edam cheese. Food Technol. Biotechnol. 2014, 52, 439-447. [CrossRef]

40. Wang, H.; Yang, L.; Ping, Y.; Bai, Y.; Luo, H.; Huang, H.; Yao, B. Engineering of a Bacillus amyloliquefaciens strain with high neutral protease producing capacity and optimization of its fermentation conditions. PLoS ONE 2016, 11, 0146373. [CrossRef]

41. Chaudhuri, M.; Biswas, S.; Pal, A.; Paul, A.K. Proteolytic Activity of Bacillus amyloliquefaciens UEF01 endophytic to carnivorous plant Utricularia exoleta R. Br. Biotechnol. J. Int. 2017, 17, 1-11. [CrossRef]

42. Samad Abd, N.S.; Amid, A.; Jimat, D.N.; Shukor, N.A.A. Protease purification from Bacillus amyloliquefaciens B7 using Aqueous Two-Phase System (ATPS). Int. Food Res. J. 2017, 24, $292-297$.

43. Strongin, A.Y.; Izotova, L.S.; Abramov, Z.T.; Gorodetsky, D.I.; Ermakova, L.M.; Baratova, L.A.; Belyanova, L.P.; Stepanov, V.M. Intracellular serine protease of Bacillus subtilis: Sequence homology with extracellular subtilisins. J. Bacteriol. 1978, 133, 1401-1411. [PubMed]

44. Jones, E.W. Three proteolytic systems in the yeast Saccharomyces cerevisiae. J. Boil. Chem. 1991, 266, 7963-7966. 
45. Atanassova, M.; Fernández-Otero, C.; Rodríguez-Alonso, P.; Fernández-No, I.; Garabal, J.; Centeno, J.A. Characterization of yeasts isolated from artisanal short-ripened cows' cheeses produced in Galicia (NW Spain). Food Microbiol. 2016, 53, 172-181. [CrossRef]

46. Klein, N.; Zourari, A.; Lortal, S. Peptidase activity of four yeast species frequently encountered in dairy products-comparison with several dairy bacteria. Int. Dairy J. 2002, 12, 853-861. [CrossRef]

47. Hansen, T.K.; Jakobsen, M. Taxonomical and technological characteristics of Saccharomyces spp. associated with blue veined cheese. Int. J. Food Microbiol. 2001, 69, 59-68. [CrossRef]

48. Seredyński, R.; Wolna, D.; Kędzior, M.; Gutowicz, J. Different patterns of extracellular proteolytic activity in W303a and BY4742 Saccharomyces cerevisiae strains. J. Basic Microbiol. 2017, 57, 34-40. [CrossRef]

49. Beniwal, A.; Saini, P.; Kokkiligadda, A.; Vij, S. Physiological growth and galactose utilization by dairy yeast Kluyveromyces marxianus in mixed sugars and whey during fermentation. 3 Biotech. 2017, 7, 349. [CrossRef]

50. Ramírez-Zavala, B.; Mercado-Flores, Y.; Hernández-Rodríguez, C.; Villa-Tanaca, L. Purification and characterization of a lysine aminopeptidase from Kluyveromyces marxianus. FEMS Microbiol. Lett. 2004, 235, 369-375. [CrossRef]

51. Deeth, H.C.; Touch, V. Methods for detecting lipase activity in milk and milk products. Aust. J. Dairy Technol. 2000, 55, 153-168.

52. Chen, Q.; Kong, B.; Han, Q.; Xia, X.; Xu, L. The role of bacterial fermentation in lipolysis and lipid oxidation in Harbin dry sausages and its flavour development. LWT 2017, 77, 389-396. [CrossRef]

53. Karami, M. RETRACTED: Enhancing the lipolysis of feta-type cheese made from ultrafiltered cow's milk. LWT 2017, 80, 386-393. [CrossRef]

54. Aponte, M.; Blaiotta, G. Selection of an autochthonous Saccharomyces cerevisiae strain for the vinification of "Moscato di Saracena", a southern Italy (Calabria Region) passito wine. Food Microbiol. 2016, 54, 30-39. [CrossRef]

55. Rodríguez-Gómez, F.; Arroyo-Lopez, F.N.; López-López, A.; Bautista-Gallego, J.; Garrido-Fernandez, A. Lipolytic activity of the yeast species associated with the fermentation/storage phase of ripe olive processing. Food Microbiol. 2010, 27, 604-612. [CrossRef]

56. Hernández, A.; Martín, A.; Aranda, E.; Pérez Nevado, F.; Córdoba, M.G. Identification and characterization of yeasts isolated from the elaboration of seasoned green table olives. Food Microbiol. 2006, 24, 346-351. [CrossRef]

57. Cardoso, V.M.; Borelli, B.M.; Lara, C.A.; Soares, M.A.; Pataro, C.; Bodevan, E.C.; Rosa, C.A. The influence of seasons and ripening time on yeast communities of a traditional Brazilian cheese. Food Res. Int. 2015, 69, 331-340. [CrossRef]

58. Meng, Z.; Zhang, L.; Xin, L.; Lin, K.; Yi, H.; Han, X. Technological characterization of Lactobacillus in semihard artisanal goat cheeses from different Mediterranean areas for potential use as nonstarter lactic acid bacteria. J. Dairy Sci. 2018, 101, 2887-2896. [CrossRef]

59. Collins, Y.F.; McSweeney, P.L.; Wilkinson, M.G. Lipolysis and free fatty acid catabolism in cheese: A review of current knowledge. Int. Dairy J. 2003, 13, 841-866. [CrossRef]

60. Falcinelli, S.; Picchietti, S.; Rodiles, A.; Cossignani, L.; Merrifield, D.L.; Taddei, A.R.; Maradonna, F.; Olivotto, I.; Gioacchini, G.; Carnevali, O. Lactobacillus rhamnosus lowers zebrafish lipid content by changing gut microbiota and host transcription of genes involved in lipid metabolism. Sci. Rep. 2015, 5, 9336. [CrossRef]

61. Cai, X.; Ma, J.; Wei, D.-Z.; Lin, J.-P.; Wei, W. Functional expression of a novel alkaline-adapted lipase of Bacillus amyloliquefaciens from stinky tofu brine and development of immobilized enzyme for biodiesel production. Antonie Leeuwenhoek 2014, 106, 1049-1060. [CrossRef]

62. Saengsanga, T.; Siripornadulsil, W.; Siripornadulsil, S. Molecular and enzymatic characterization of alkaline lipase from Bacillus amyloliquefaciens E1PA isolated from lipid-rich food waste. Enzym. Microb. Technol. 2016, 82, 23-33. [CrossRef]

63. Abbasiliasi, S.; Tan, J.S.; Ibrahim, T.A.T.; Bashokouh, F.; Ramakrishnan, N.R.; Mustafa, S.; Ariff, A.B. Fermentation factors influencing the production of bacteriocins by lactic acid bacteria: A review. RSC Adv. 2017, 7, 29395-29420. [CrossRef] 
64. Oliveira, L.D.C.; Silveira, A.M.M.; Monteiro, A.D.S.; Dos Santos, V.L.; Nicoli, J.R.; Azevedo, V.A.D.C.; Soares, S.D.C.; Dias-Souza, M.V.; Nardi, R.M.D. In silico prediction, in vitro antibacterial spectrum, and physicochemical properties of a putative bacteriocin produced by Lactobacillus rhamnosus strain L156.4. Front. Microbiol. 2017, 8, 876. [CrossRef]

65. Drosinos, E.H.; Mataragas, M.; Paramithiotis, S. Antimicrobial activity of bacteriocins and their applications. In Meat Biotechnology; Springer Science and Business Media LLC: Berlin/Heidelberg, Germany, 2008; pp. 375-397.

(C) 2019 by the authors. Licensee MDPI, Basel, Switzerland. This article is an open access article distributed under the terms and conditions of the Creative Commons Attribution (CC BY) license (http://creativecommons.org/licenses/by/4.0/). 